\title{
14
}

\section{Digital Learning Environments}

\author{
George Veletsianos
}

\subsection{Introduction}

Learning environments are ubiquitous. Schools, universities, workplaces, professional organizations, community groups, families, religious groups, museums, after-school programs, and peer groups are environments that provide opportunities for learning and socialization. As digital technologies saturate our lives and participation in online environments soars, both the number and the variety of digital learning environments are growing exponentially. Video games, social networking sites, open courses, and a variety of social and networked technologies provide individuals with opportunities to learn content and competencies, and adopt new behavior patterns. Growing numbers of learners are taking courses online (Allen and Seaman 2013) and governments, elected officials, and interest groups are encouraging the development of digital learning opportunities (e.g., European Commission 2013).

Digital learning environments are central to endeavors to design, develop, and deliver digital learning opportunities. While the LMS (e.g., Blackboard, Desire2Learn, Moodle, Instructure Canvas) is often used in such initiatives, a number of other digital learning environments have been adopted (e.g., blogging platforms, social media, and other standalone digital environments). We note that the terms LMS and VLE refer to the same technology. The term LMS is used in this chapter.

The notion of the learning environment is associated with the constructivist movement (Wilson 1995, 27), as emphasis has moved from the individual (e.g., student, instructor), to the context, to the place and space surrounding learning and instruction. Wilson argues: "learning environments seem intrinsically fuzzy and ill-defined. That is, an environment that is good for learning cannot be fully prepackaged and defined. If students are involved in choosing learning activities and controlling pace and direction, a level of uncertainty and uncontrolledness comes into play." The increasing use of digital technologies in education gave rise to the notion of the digital learning environment. Yet, digital learning environments are also ill-defined.

The Wiley Handbook of Learning Technology, First Edition. Edited by Nick Rushby and Daniel W. Surry. (c) 2016 John Wiley \& Sons, Inc. Published 2016 by John Wiley \& Sons, Inc. 
While they can constitute "educational software, a digital learning tool, an online study program or a learning resource" (Suhonen and Sutinen 2006, 43), they can also be technologies, resources, platforms, and systems originally created for purposes other than education, but which came to be used for teaching and learning purposes. This broad and inclusive perspective on what constitutes a digital learning environment recognizes the wide variety of learning environments that exist regardless of the original intent of their developers.

Researchers and learning designers are examining a number of issues surrounding the use of digital learning environments. At the forefront of these investigations are investigations of the opportunities for learning and instruction that different digital learning environments afford, the ways that informal learning environments can effectively be used in teaching and learning, the experiences that learners and instructors have within these, the ways that open learning environments can contribute to the education enterprise, and the ways that a diverse array of data can be collected, analyzed, and displayed by the learning environment to improve teaching, learning, and learner experiences.

This chapter introduces the reader to four foundational and emerging issues facing individuals who are engaging with the design, development, and evaluation of digital learning environments. These are the following:

- organizational structures used to categorize digital learning environments

- the design of digital learning environments for effective and meaningful learning experiences

- the debate on guided vs minimally guided instruction within digitallearning environments

- the issue of appropriated and repurposed digital learning environments being rarely neutral.

The latter three of these four issues are accompanied with short case studies to illustrate the issues examined.

\subsection{Organizational Structures}

Digital learning environments offer instructional and learning opportunities that involve student-student, student-content, and student-teacher interactions (Moore 1989), as well as teacher-content, teacher-teacher, and content-content interactions (Anderson and Garrison 1998). These interactions occur within a number of organizational structures, such as groups, networks, and communities, and an understanding of these structures enables designers and researchers to make sense of how individuals within them may interact with each other.

According to Dron and Anderson (2009), groups represent hierarchical and formal entities in which participants know each other and their entry to and exit from the group are controlled. An example of a group is a face-to-face or online course that is organized by an educational institution and has one or more instructors and one or more students. Entry to, and exit from, the course are controlled, as the course has a start and end date, and, in all likelihood, learners within the group will know each other. Groups are often hosted within digital learning environments, traditionally within an LMS as this technology is popular with higher education institutions (Mott 2010; Paulsen 2003) and allows institutional control over access. 
Alternatively, Dron and Anderson (2009) define networks as fluid and generative entities consisting of distributed participants. While groups have boundaries, networks do not, and it is difficult to establish who is in and who is not in a network. Entry to, and exit from, networks is generally unrestricted, and individuals may know some, but not all, other members involved in the network. Individuals within networks have both strong and weak ties to each other. Dalsgaard (2008) argues that networks are comprised of many different individual networks, each consisting of individuals' relationships with other members of the network. For example, Figure 14.1 shows my network of networks, consisting of colleagues, peers, and friends.

Different networks exist for different purposes and their dynamics and qualities vary. Ito et al. (2010) studied youth and youth culture and noted that differences exist between activity-driven and friendship-driven participation in networks. Friendship-driven participation is exemplified by youths' behavior and interactions with peers as they go about their day-to-day activities. In contrast, interest-driven participation describes activities structured around interests, hobbies, and/or career aspirations.

An example of a learning network driven by interest may be the people who gather on an online social network (e.g., Facebook, Meetup.com) to explore and learn about the health benefits and ethical implications of veganism and plant-based diets. Networks like this have low entry and exit barriers (e.g., clicking a "join" or "leave network" button allows participants

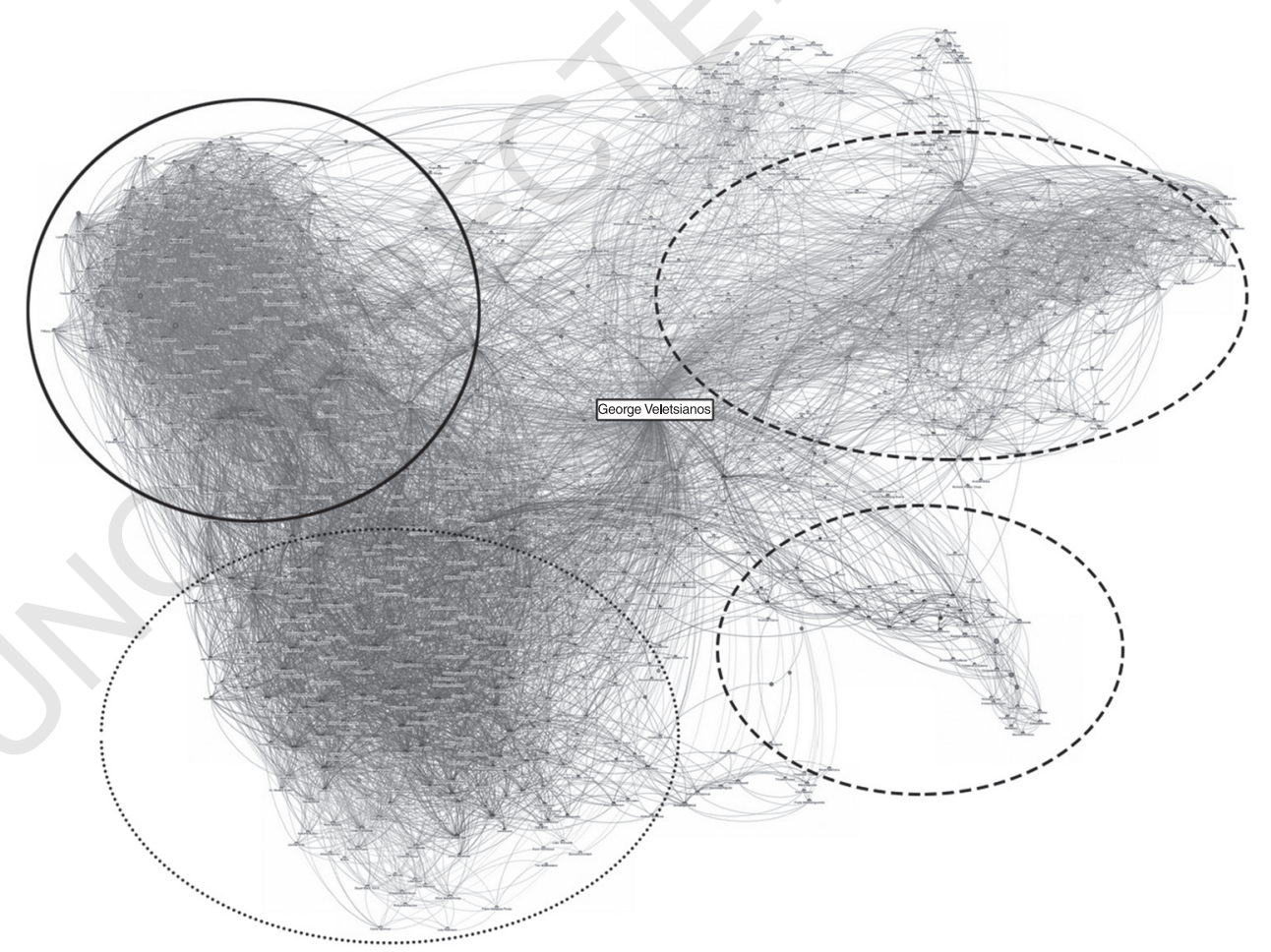

Figure 14.1 A visualization of the author's network from LinkedIn. Each node represents an individual and each tie represents a relationship between two nodes. Each node is connected to other nodes/networks not shown here. This image was created using inMaps, using data from LinkedIn. 
to come and go as they wish). Participants may be distributed, discussions may be spontaneous, and members may know each other very well (e.g., a couple may join the same network), may be familiar with each other (e.g., acquaintances who know each other from other networks), or may not know others at all (e.g., individuals who are curious and joined this group after having stumbled upon it via a search engine).

Networks are an organizational structure and may exist within digital learning environments. The digital environments most closely associated with networks are social networking sites (e.g., Twitter, Facebook, Elgg), which Boyd and Ellison $(2007,211)$ define as "web-based services that allow individuals to (1) construct a public or semi- public profile within a bounded system, (2) articulate a list of other users with whom they share a connection, and (3) view and traverse their list of connections and those made by others within the system." Networks can also span multiple digital learning environments. For example, doctoral students' professional network might include peers, professors, and colleagues who are dispersed across multiple environments. These individuals might be connected with the doctoral student on multiple environments (e.g., both on an institutional and a commercial platform).

The term community is frequently encountered in the education literature. While the organizational structure of a network may approximate that of a community, the two are distinct, as networks are relatively loose and communities appear to exhibit commitment, coherence, and continuity. Researchers categorize communities in different ways. For example, Henri and Pudelko (2003) identify four types of virtual communities: communities of interest, goal-oriented communities of interest, learners' community, and community of practice. Riel and Polin (2004) identify three types of learning communities: task-based, practice-based, and knowledge-based.

While community appears to be a valued quality of digital learning environments, exactly what is meant by the term "community," what qualities make an online community attractive, and what steps designers, instructors, and facilitators should take to encourage and nurture communities is under investigation (Barab, Kling, and Gray 2004). However, Barab and Duffy (2000) identified four defining characteristics of communities that contribute to a better understanding of this organizational structure. Communities (1) have shared histories and cultures, (2) have shared goals and practices, (3) are part of something larger than the individuals participating in them, and (4) reproduce, with member roles in the community shifting, evolving, maturing, and changing. Barab, MaKinster, and Scheckler (2004) further suggest that communities may also encompass meaningful relationships and respect for diversity. These characteristics point to the complexity inherent in virtual communities and the difficulty in designing digital learning environments to foster, support, and sustain them (Barab, Kling, and Gray 2004).

One type of community that has received wide attention in the literature is the community of practice (CoP; Lave and Wenger 1991; Wenger 1998). CoPs exist in both digital and face-to-face environments. The purposes and practices of CoPs vary widely. For instance, CoPs focus on hobbies (e.g., gardening, knitting), professional practice (e.g., real estate agents, teachers of English), and other interests (e.g., software development, photography, etc.). Wenger $(1998,2)$ describes CoPs as "groups of people who share a concern or a passion for something they do and learn how to do it better as they interact regularly." According to Wenger, three dimensions important to CoPs are: mutual engagement, negotiation of a joint enterprise, and a shared repertoire. The mutual pursuit of 
collective activities binds people together into a social entity. The enterprise is the result of a collective process negotiated over time and is defined by the participants pursuing it (e.g., distributed programmers developing the Linux Operating System and supporting each other in this endeavor). Pursuing a joint enterprise over time creates a shared repertoire of resources through which meaning is created. This shared repertoire includes "routines, words, tools, ways of doing things, stories, gestures, symbols, genres, actions or concepts" (Wenger 1998, 83).

Groups, networks, and communities are organizational structures that function within digital learning environments. Some digital learning environments support specific types of organizational structures and create boundaries to maintain those (e.g., LMS most often support and maintain groups), while others are more fluid. This is important because the type of organizational structure present impacts learning and teaching within a digital learning environment. For instance, teaching a group might require different instructional and assessment strategies than facilitating learning in a network.

\subsection{Designing Learning Environments and Learning Experiences}

The importance of design for digital learning environments cannot be overemphasized. Learning designers play a significant role in working with faculty members, media developers, and researchers in the design and development of digital learning environments and need to carefully consider how to design digital learning environments to foster effective, meaningful, and impactful learning experiences. Wilson $(2004,78)$ argues: "it makes good sense to talk about design of overall environments for e-Learning, because the entire [learning] experience is mediated by technology." Merrill $(2008,162)$ posits: "far too much instruction is still not effective, not efficient, and not engaging." He goes on to argue that, when it comes to designing learning environments, "we have just scratched the surface of how to design what to teach and how to teach."

In their book, How People Learn, Bransford, Brown, and Cocking (1999) summarize four perspectives that could guide the design of effective learning environments:

1. Learner-centered. Learning environments should respect the experiences, knowledge, attitudes, and culture that the learner brings to the environment.

2. Knowledge-centered. Learning environments should enable learners to become knowledgeable in a discipline and transfer their learning to new domains. At the same time, effective learning environments should emphasize sense-making and enable learners to make connections between objectives and information such that they gain a holistic perspective of the discipline they are studying.

3. Assessment-centered. Learning environments should provide assessment (both formative and summative) and feedback, and should strive to assess understanding and not just knowledge recall.

4. Community-centered. The community in which the learning environment is situated is critical. Designers should understand the community and create learning environments that support, reflect, and respect the community's realities, aspirations, and social norms. 
While these perspectives are foundational to the design of learning environments, more recent work has both refined and extended our understanding of effective learning environments. For example, Reeves (2006) argues that assessment, especially in higher education settings, should focus on higher-order outcomes for deeper learning and should support cognitive, affective, conative, and psychomotor aspects of learning. Furthermore, as learning processes in networks may differ from learning processes in groups, Downes (2010) suggests that networked learning environments should be designed to maximize learner autonomy, diversity, openness, and interactivity, enabling greater freedom and democratization.

Increasingly, learning designers and researchers are questioning whether prevailing instructional design principles can enable high-quality learning experiences that are empowering and inspirational. Wilson, Parrish, and Veletsianos (2008) note that highquality learning experiences are rare and suggest that educators and designers should aim to design socially just and transformational learning experiences, and not simply pursue instruction that is effective and efficient. Veletsianos (2011) provides further practical suggestions towards these goals. He argues that while designers may not be able to construct transformative learning experiences for students, they should aim to provide learners with opportunities to engage with potentially transformative learning experiences. He suggests that designers should:

- design opportunities that allow engagement beyond course activities

- design for lasting impression

- design for intrigue, risk-taking, and challenge

- design for engagement

- design for reflection.

In a similar fashion, Wilson and Parrish $(2011,10)$ encourage designers to design learning experiences that are "especially meaningful" and leave "a lasting impact on a person's sense of competence or place in the world." They suggest that designers should create the conditions under which transformational learning experiences can occur and offer the following guidelines:

- Designers should apply design fundamentals (e.g., by aligning outcomes, activities, and assessments, applying constructivist learning principles such as student-centered design).

- Designers should craft the learning experience (e.g., by challenging learners, using interactive media, encouraging personal involvement).

- Designers should inspire learning (e.g., by showing care and commitment to learning).

While there is still much to learn about the design of effective, meaningful, inspirational, empowering, and caring learning environments, empirical research on design practice provides insightful suggestions for designing digital learning environments that afford powerful learning experiences. With interest in digital education skyrocketing, learning designers have an opportunity to use their knowledge and expertise to meaningfully impact the creation of future learning environments. 


\subsection{Illustrative Example: The YoTeach! Learning Environment}

The following example illustrates how a digital learning environment was designed to create a rich, meaningful, and engaging learning experience.

The YoTeach! learning environment was developed for introductory-level sociology courses. At the institution in which this learning environment was implemented, introductory sociology courses were divided into four to six sections, with each section having between 150 and 200 students. Each section met twice a week for a traditional 50-minute lecture and students were divided into six 1-hour discussion groups that met once a week to discuss course content. The purpose of YoTeach! was to alter the activities students engaged in to learn sociological concepts.

The development of the YoTeach! learning environment relied heavily on collaborative sessions between the designers and the sociology instructor. Based on backwards design principles, the initial sessions focused on goal analysis to identify learning objectives that "centered on big ideas and important performance challenges" (Wiggins and McTighe 2005, 195) and students' learning challenges (Dick, Carey, and Carey 2009), essentially seeking to apply design fundamentals per the suggestions provided by Wilson and Parrish (2011). Next, designers sought to craft the learning experience and inspire learning following suggestions delineated in Veletsianos (2011) and Doering (2006). In an effort to increase student engagement, understanding, and opportunities for meaningful investigation, the design team decided to (1) use a blog as the primary learning environment for content delivery, (2) collect topical crowd-sourced videos, (3) create mini-documentaries from filmed interviews of local community members, (4) use the university's learning management system for online discussions, and (5) allow students to apply their learning by either writing blog entries or filming their own mini-documentary.

The digital learning environment consisted of a constellation of technologies and spaces. The environments hosted content, resources, curricular activities, and learnerlearner, learner-expert, and learner-instructor interactions. The topic examined in this initiative was the relationship between personal actions and social forces. This is a sociological topic that is often examined in introductory courses, and in this course the decision was made to examine this topic through the lens of teacher activities (i.e., How do social forces influence teacher actions?). The team traveled to various communities in the local city and asked participants to respond to the following prompts: (1) What is the role of the teacher? and (2) Tell us a story about a memorable teacher. Responses were filmed and edited to portray various beliefs about the teacher's role (Figure 14.2). In addition, the team received contributions (e.g., audio and video contributions) from individuals across the United States. The artifacts collected were used in two ways. All videos (team-recorded interviews and crowd-sourced video contributions) were posted on a blog page to enable student exploration and use within the classroom. The videos were compiled into three 5-minute long "documentaries," with each documentary focusing on a central theme relevant to the content area. Students were assigned to groups and asked to (1) follow the team's journey as members traveled into the community collecting and posting stories, (2) interact with the team and other experts contributing to the project, (3) develop multimodal blog entries or videos to examine a sociological issue, (4) share their projects with the rest of the class, and (5) within their discussion groups, post two public comments on other projects. 


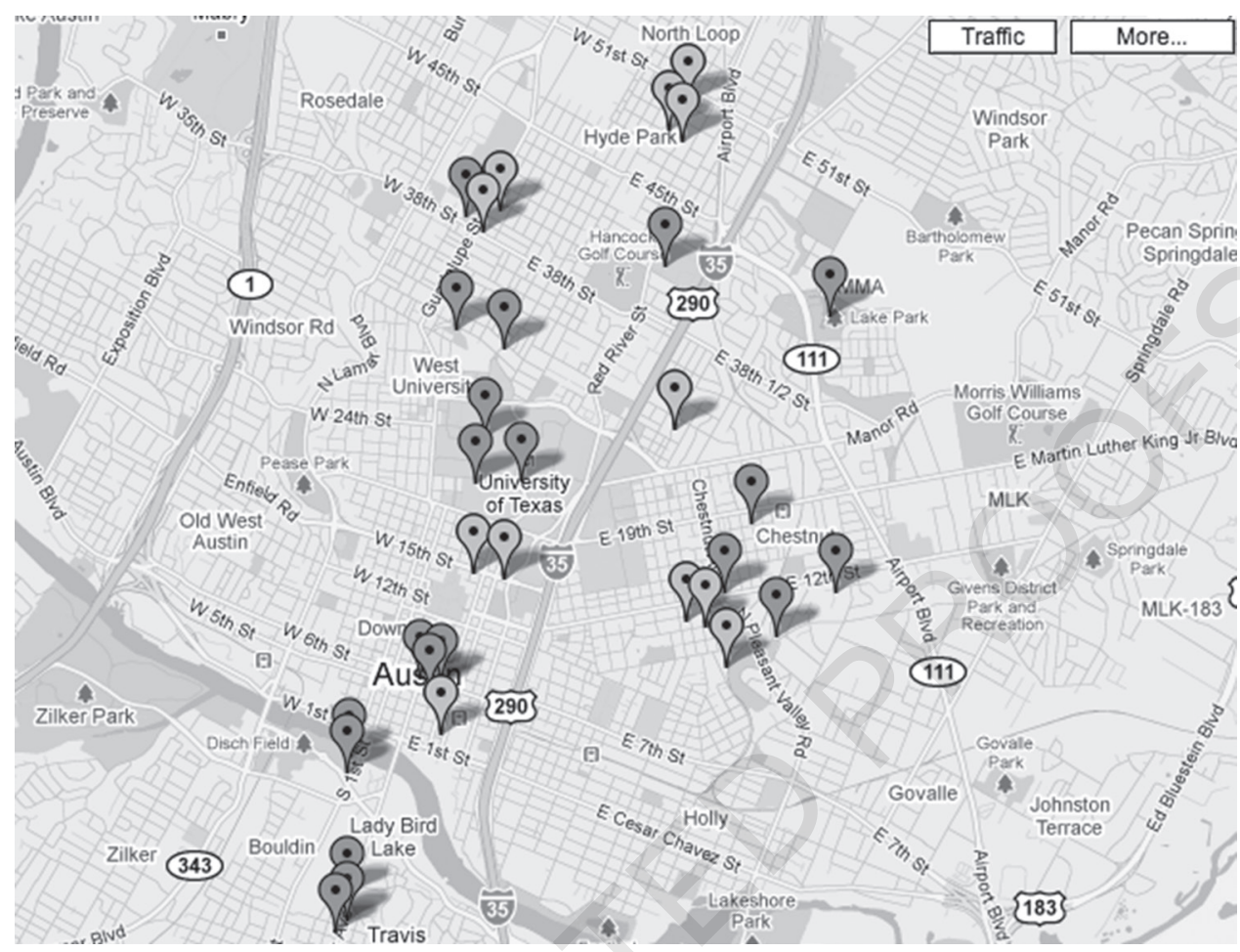

Figure 14.2 Interview locations were shared on a map to contextualize the data collected (๑ Google Maps).

By utilizing a blog format, the YoTeach! design team was able to effortlessly control content delivery and availability (Bar-Ilan 2005). The primary content, the mini-documentaries and explanatory text, was divided in distinct blog entries. However, to provide learners with greater control, all of the crowd-sourced videos were made available on video-sharing sites and embedded in a supplementary section of the blog, allowing students to progress at their own speed. The YoTeach! environment let students re-visit blog entries and videos for clarification and modeling purposes. The university's learning management system allowed smaller groups of students to discuss the content and concepts in a secure environment (Bradford et al. 2007).

Several features made this digital learning environment and learning experience innovative. The traditional "lecture plus lab" course was transformed into an environment in which students were engaged in hands-on, community-based activities. In addition, the course offered variety and mystery, the videos connected sociological theory to the real world, students used data to answer sociological questions, and students were afforded autonomy in their investigations and final projects. Furthermore, the YoTeach! learning environment challenged prevailing approaches to instruction. Instruction is often thought of as something that instructors impart to learners and technology is frequently used to support passive and didactic instruction (Herrington et al. 2009). Efforts to integrate technology have often produced courses with traditional instructional approaches that are only technologically reinforced, but not qualitatively different (Cuban 1988; Hughes 2005; 
Wilson, Parrish, and Veletsianos 2008). To tackle this problem, the digital environment re-envisioned the curriculum and the pedagogical premises of the sociology course, and enabled students to experience authentic sociological investigations and to take participatory and vested roles in their learning. Students were supported in becoming knowledge creators rather than just passive knowledge consumers and were empowered to gain, create, and share their knowledge with others.

\subsection{Guided vs Minimally Guided Instruction within Digital Learning Environments}

The increasing abundance of freely available curricula, lectures, and information in the form of texts, videos, and multimedia on the Internet has enabled learners to access a wide array of high-quality content. Content is no longer scarce (Weller 2011) and learners can often access it freely from a number of sources, including institutional repositories (e.g., MIT OpenCourseWare), open course providers (e.g., EdX), and social media sites (e.g., YouTube instructional videos). Yet, instruction is not just content delivery. Merrill $(2008,23)$ notes that "there seems to be an assumption that information is sufficient and that [effective, efficient, and engaging] direct instruction is no longer necessary ... The Internet is swollen with information, and amidst this flood, there are only isolated islands of [effective, efficient, and engaging] instruction." Indeed, design, and the design of learning experiences, is one of the cornerstones of the learning technologies (Reeves 1997; Conole 2013; Smith and Boling 2009; Gibbons and Yanchar 2010). Though approaches may deviate slightly, designers typically engage in iterative design processes in which they identify problems or opportunities, analyze learning contexts, define educational objectives, design and develop assessments, develop instructional strategies, activities, and learning materials, and design and conduct evaluations. Systematic processes like the one just described aim to create learning environments that engender learning opportunities and provide scaffolds for learning. In designing a digital learning environment scholars and practitioners are faced with the following questions: How much and what kind of instruction, guidance, and support do learners require? How much structure do learners need in a learning environment? How much guidance do they need? Though the field has debated these issues, the topic has received renewed interest recently with the development of MOOCs. The questions that practitioners and researchers are currently contemplating within this context are: How much and what types of support can peers provide to each other in a learning environment? What is the role of the instructor in open online courses? How much structure do different types of learners need in open courses?

The debate concerning the relative merits of guided vs minimally guided instruction is important in the examination of digital learning environments. Direct instructional guidance is defined as "providing information that fully explains the concepts and procedures that students are required to learn as well as learning strategy support that is compatible with human cognitive architecture," while unguided or minimally guided instruction (e.g., discovery-based learning) is defined as "one in which learners, rather than being presented with essential information, must discover or construct essential information for themselves" (Kirschner, Sweller, and Clark 2006, 75). Kirschner, Sweller, and Clark contend that guided instruction is more effective and efficient than minimally guided instruction. They suggest 
that minimally guided instruction (defined to include constructivist, discovery-based, problem-based, experiential, and inquiry-based learning methods) overloads working memory and minimal guidance during instruction is ineffective in altering long-term memory structures (i.e., learning). Working memory is a location of limited capacity and duration that humans use to store and process information. By overloading working memory, minimally guided instruction hinders learning. Kirschner, Sweller, and Clark claim that guided instruction does not overload working memory and supports the foundations of human cognition.

In response, Hmelo-Silver, Duncan, and Chinn (2007) counter that problem-based learning (PBL) and inquiry learning (IL) are highly scaffolded and therefore not in the same category as the "extreme" unguided instructional approaches described by Kirschner and colleagues. Hmelo-Silver et al. present evidence for the effectiveness of PBL and IL, and claim that educational goals should extend beyond changes in long-term memory, for instance educational goals should include the ability to cooperate with others to solve problems.

In turn, Sweller, Kirschner, and Clark (2007) argue that the studies cited by Hmelo-Silver et al. are problematic because they compare learners who used an existing curriculum to learners who were presented with a new curriculum. Such approaches, they argue, are problematic because (1) the extent to which teachers in the control groups used inquiry-learning methods and (2) the extent to which the results of the studies are due to the new curriculum itself rather to other (uncontrolled) variables cannot be established. Furthermore, these authors suggest that comparing pedagogies across groups is ineffective because more than one variable changes at a time, and since researchers do not know which variable causes differences between groups, arguing across pedagogies is perilous.

When designing digital learning environments, designers face a number of constraints and opportunities, and make decisions about pedagogies and instructional guidance. The example that follows illustrates how a digital learning environment embedded support structures and scaffolds for teachers and learners in the context of a problem-based learning initiative.

\subsection{Illustrative Example: Project Engage!}

Project Engage! involved the design and development of a computer science (CS) highschool course supported by a digital learning environment. The project aimed to enhance CS education and create an innovation that was flexible enough to scale to numerous schools and adapt to local contexts without losing its essence. The scalability goal introduced a number of constraints. One of the decisions that designers needed to make was the degree of instructional guidance that needed to exist within this initiative.

The types of CS courses currently offered in US high schools are problematic as they traditionally focus on programming or technology applications (Burns 2011; Simard, Stephenson, and Kosaraju 2010). For instance, even though computer scientists need an understanding of algorithms and data structures, traditional high-school CS courses teach programming or uses of productivity tools (e.g., Microsoft Excel). To address the need for new CS curricula, the National Science Foundation and the college board released a list of objectives representing the "big ideas" that CS students need to know (CS principles). 


\section{PROJECTS contextualize instruction}
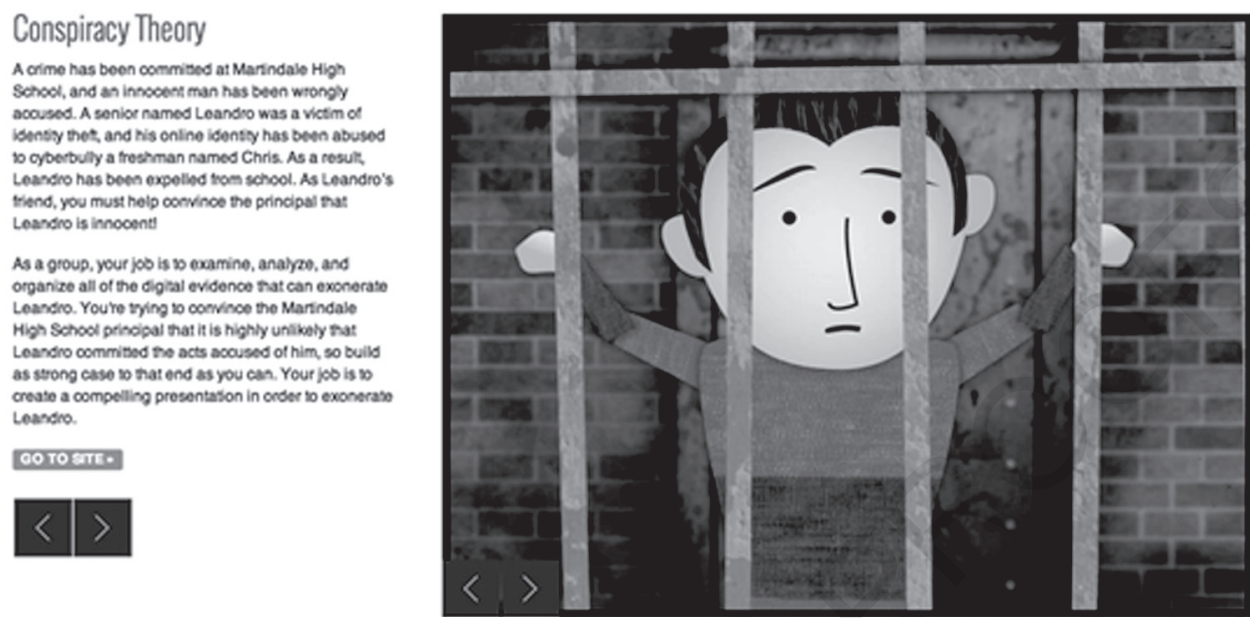

Figure 14.3 Introduction to the Innovations Module.

A number of elements made the course appealing to students and administrators. The course was offered as a dual credit option (i.e., provided college credit) and featured a blended model of instruction. It was grounded on a problem-based pedagogy, and the content of the course was framed in terms of relevant and authentic problems that students needed to solve. The content within the learning environment was organized into modules, each representing a significant area of CS, for example the artificial intelligence (AI) module asked students to create video game components that made use of AI strategies and the innovations module asked students to examine a trail of digital evidence to identify the perpetrators of a cyberbullying campaign against a peer (Figure 14.3).

CS instruction at high-school level often involves direct instruction, and this initiative departed from that norm. While direct instruction was still present, the design team introduced a number scaffolds in the digital learning environment to support students with the problem-solving process. For example, learners were asked to maintain KWL (Know-Want to know-Learned) charts to keep track of their learning and their knowledge gaps during modules. Teachers were trained so they could work with ill-structured problems and provide scaffolding to help students when solving problems (e.g., teachers were trained in holding tutorial meetings with student teams to discuss their progress).

\subsection{Repurposed Digital Learning Environments and their Neutrality}

A number of authors have argued that the field suffers from technological determinism (Oliver 2011), focusing on the promises and potential of technology instead of examining the broader socio-scientific issues relevant to the field, including its politics and ideologies (Selwyn 2011). One of the issues associated with technological determinism is the fact that 
technologies are rarely neutral. This issue becomes significant when researchers, designers, and educators repurpose digital learning environments not originally designed for educational purposes and use them as digital learning environments.

Digital technologies are often appropriated and repurposed as digital learning environments to meet educational objectives (Veletsianos 2010). Some digital environments are created specifically for educational purposes while others serve educational functions even though they were originally created for other purposes, for example Alien Rescue (Alien Rescue 2014) is a problem-based digital learning environment to support science learning in middle school (Liu, Williams, and Pedersen 2002) and AvenueASL (Avenue 2014) is a digital learning environment that allows students to record and submit and instructors to assess American Sign Language (Miller, Hooper, and Rose 2008). A number of digital environments, however, are not specifically designed for learning and teaching. For instance, designers and educators have used Facebook as a learning management system (Wang et al. 2012), Twitter as an instructional tool (Elavsky, Mislan, and Elavsky 2011; Junco, Heiberger, and Loken 2011), YouTube as a learning resource (Burke and Snyder 2008), virtual worlds as experiential learning environments (Jarmon et al. 2009), and video game consoles as physical education supplements (Staiano and Calvert 2011). Students have also adopted a number of technologies to supplement course materials, aid their studies, collaborate, and enrich their learning. For instance, Jenkins et al. (2006) describe how students learn how to collaborate and problem-solve by engaging with participatory media and Selwyn (2009) examines how students engage with the day-to-day realities of being a student through Facebook.

Why is the appropriation and repurposing of digital environments significant? This topic is important because neither technologies nor preferred approaches to instruction are neutral (Veletsianos 2010, 2012; Veletsianos and Kimmons 2012, 2013; Veletsianos, Kimmons, and French 2013), and the repurposing of digital technologies may create tensions in educational institutions (Crook 2012). Technology is created with the developers' world views, values, beliefs, and assumptions embedded into its design. These world views are revealed through the activities supported and encouraged by the technology. For instance, the assumption that learning in digital learning environments is guided and managed by the instructor leads to the development of tools within LMSs that favor hierarchical relationships. In practical terms, such an assumption reveals itself in default settings and tools that provide predetermined perspectives on how education in digital environments is enacted (Lane 2009). Two simple examples are (1) discussion boards that do not allow learners to create new threads and (2) the presence of tools (e.g., wikis) that can only be used after being instantiated by the instructor. Social networking sites (SNSs) face a similar issue. SNSs foster certain kinds of relationships, which have important implications when technologies are used as digital learning environments. The range of relationships afforded by contemporary social media (e.g., friends, followers, etc.) are relatively flat and are not representative of the full spectrum of relationships seen or hoped for in educational settings. Given that social media may espouse a particular view of the world (Kimmons 2012), learning designers and instructors should consider whether this particular world view aligns with their values and the ideal learning environment that they strive to create. In repurposing technologies for use as digital learning environments, designers and instructors should examine how technology's lack of neutrality will impact their instructional practices and learners' experiences. 
Instructional practices are influenced by a range of powerful contextual factors (Britzman 2003), such as an instructor's past experiences as a student (Lortie 1975) and an instructor's beliefs (Ertmer 2005). This is not to say that repurposing technology will be detrimental to academic practice. Certain values imbued in technologies may provide opportunities and affordances that improve academic practice, for instance social technologies have enabled instructors to create open learning environments (Couros 2010). On the one hand, instructors may use new digital learning environments to replicate and support familiar practices. Veletsianos, Kimmons, and French (2013), for example, found that when a social networking site was introduced into a university setting to replace the existing LMS, a number of instructors viewed the site as a "repository for information to disseminate to students," and perceived the platform as "a virtual filing cabinet," a "dumping ground for ideas," and a place that would help students to "either put documents or take documents away." On the other hand, instructors may change their teaching practice to accommodate a specific technology (West, Waddoups, and Graham 2007). For example, the introduction of a new learning management system might allow instructors to embrace more student-centered practices by effortlessly managing discussion forums.

The example that follows illustrates the notion of repurposed and appropriated technologies, highlighting how certain values imbued in the technology provide alternative opportunities for learning and participation.

\subsection{Illustrative Example: Twitter and \#PhDChat}

Twitter is a flexible technology that has proven efficient and effective in many contexts, as it allows participants to build and navigate networks and disseminate information. While some academics may bemoan the platform (e.g., Wakefield 2013), others have found value in it, for instance scholars participating on Twitter share information, resources, and media, request assistance from and offer suggestions to others, engage in social commentary and impression management, seek to network and make connections with others, and highlight their participation in online networks other than Twitter (Veletsianos 2012). In this way, Twitter frequently becomes part of a constellation of tools that individuals use to learn and participate online.

Even though Twitter has been used as a learning tool, its appropriation and repurposing as a learning environment is most clearly seen via the use of hashtags. A hashtag is a simple \# symbol followed by a phrase (e.g., \#K12, \#edtech, \#AERA2015). Hashtags are commonly used to label a message (e.g., "Here is an excellent report on the use of smartphones in education: [link to report] \#mobile-Learning \#edtech"). Labels (i.e., hashtags) enable users to group and retrieve messages around a common topic. This practice has allowed users to form networks around shared interests and practices (Parker 2011), in the process creating hashtag networks which can be viewed as a particular type of digital learning environment.

One hashtag network, is \# $\mathrm{PhDChat}$. This network arose when a group of UK doctoral students began using it in 2010 to hold discussions related to pursuing a doctoral degree (Thackray n.d.). Students convened weekly to discuss specified topics and over time \#PhDChat's membership grew, with individuals often using the network to provide emotional and academic support to each other (Ford, Veletsianos, and Resta 2014). In the dedications 
and acknowledgements section of her dissertation, for example, Folley $(2012,8)$ highlights the value of this digital environment for her work and writes: "[T]hanks to all those on \#PhDChat on Twitter, too many to name individually, for their enormous help, moral support, motivation and kindness. PhDChat is a great example of the affordances of social media, providing a personal learning network of doctoral students worldwide supporting and collaborating together."

\subsection{Conclusion}

This chapter has examined four issues that are important to consider and recognize when designing, adopting, and evaluating learning environments. Organizational structures, the design of learning experiences, the degree to which learning environments are guided, and technology's lack of neutrality within the context of repurposed learning environments, are issues that designers and researchers face when engaging with digital learning environments. While these issues are significant, they are oftentimes hidden.

The realities of day-to-day practice with learning technologies are complex. Practitioners may engage with a wide range of activities, including examining learning analytics data for formative evaluations, analyzing learner tasks, aligning assessments with objectives, locating or developing media, creating accessible user interfaces, writing code to create new/different opportunities for learning, negotiating with multidisciplinary teams as to the best approaches to learning and instruction for a particular context, and working with faculty members to improve learning environments. These activities require a diverse set of skills and mindsets, especially when they are seen in the context of the four issues described above. A critical mindset is significant for learning designers to cultivate. A critical mindset means being cognizant and vigilant of the fact that learning technologies may encompass values, beliefs, assumptions, and principles that are covert (e.g., particular technologies or pedagogies as panaceas to educational problems). Developing a critical mindset will allow learning designers to counter simplistic assumptions about design, pedagogy, and the role of technology in education, thus becoming better equipped to create effective and empowering learning opportunities supported by technology.

Researchers also need to further examine the daily realities of learning technologies practice. Significant questions that learning technologies researchers can ask are the following: What is the nature of learning and teaching under different organizational structures? How do different organizational structures enable and support different approaches to instruction and learning? What are the conditions under which the appropriation and repurposing of digital technologies becomes successful? How and under what conditions does technology's lack of neutrality impact education? What are the experiences of learners and instructors with emerging forms of education and under different organizational structures?

It is hoped that the elucidation of the issues presented above assists readers in recognizing them in the various learning environments that they encounter or design in the future. Many questions remain unresolved around the design and use of digital learning environments, and designers, instructors, researchers, and administrators need to proceed mindfully, yet boldly. Research on this emerging area of interest is both necessary and needed. 


\section{References}

Alien Rescue. 2014. Do You Have What It Takes to Save the Aliens? Accessed 19 March 2015: http:// alienrescue.edb.utexas.edu/.

Allen, I. Elaine and Jeff Seaman. 2013. Changing Course: Ten Years of Tracking Online Education in the United States. Sloan Consortium. ISBN 978-0-9840288-3-2. Accessed 19 March 2015: www. onlinelearningsurvey.com/reports/changingcourse.pdf.

Anderson, Terry D. and D. Randy Garrison. 1998. "Learning in a networked world: New roles and responsibilities." In Distance Learners in Higher Education: Institutional responses for quality outcomes, edited by Chere Gibson: pp. 97-112. Madison, WI: Atwood Publishing.

Avenue, 2014. AVE. Accessed 19 March 2015: https://avenue.umn.edu/info/\#teachers.

Barab, Sasha A. and Thomas M. Duffy. 2000. "From practice fields to communities of practice." In Theoretical foundations of learning environments, edited by David H. Jonassen and Susan M. Land: pp. 25-55. Mahwah, NJ: Lawrence Erlbaum Associates.

Barab, Sasha, Rob Kling, and James H. Gray. 2004. Designing for Virtual Communities in the Service of Learning. Cambridge: Cambridge University Press. ISBN: 9780521520812.

Barab, Sasha, James MaKinster, and Rebecca Scheckler. (2004). Designing system dualities: Characterizing online community. In Designing for Virtual Communities in the Service of Learning, edited by Sasha Barab, Rob Kling, and James H. Gray. Cambridge: Cambridge University Press.

Bar-Ilan, Judit. 2005. "Information Hub Blogs." Journal of Information Science 31 4: 297. doi: $10.1177 / 0165551505054175$.

Boyd, Dana M. and Nicole B. Ellison. 2007. "Social Network Sites: Definition, History and Scholarship." JournalofComputerMediated Communication 131:210-30.doi:10.1111/j.1083-6101.2007.00393.x

Bradford, Peter, Margaret Porcielo, Nancy Balkon, and Debra Backus. 2007. “The Blackboard Learning System: The Be All and End All in Education Instruction?" Journal of Educational Technology Systems 35 3: 301. doi:10.2190/X137-X73L-5261-5656.

Bransford, John D., Ann L. Brown, and Rodney R. Cocking. 1999. How people learn: Mind, brain, experience, and school. Washington, DC: National Research Council. Accessed 19 March 2015: www.nap.edu/openbook.php?isbn=0309070368.

Britzman, Deborah. P. 2003. Practice makes practice: a critical study of learning to teach. New York: SUNY Press. ISBN-10: 0791458504.

Burke, Sloane C. and Shonna L. Snyder. 2008. "YouTube: An Innovative Learning Resource for College Health Education Courses." International Electronic Journal of Health Education 11: 39-46. Accessed 19 March 2015: http://js.sagamorepub.com/gjhep/article/view/4168/3644.

Burns, Judith. 2011. "School ICT to be replaced by computer science programme." BBC News: Education and Family. Accessed 19 March 2015: http://www.bbc.co.uk/news/education-16493929.

Conole, Gráinne. 2013. Designing for learning in an Open World. New York: Springer. doi: 10.1007/978-1-4419-8517-0.

Couros, Alec. 2010. "Developing personal learning networks for open and social learning." In Emerging technologies in distance education, edited by George Veletsianos: pp. 109-128. Athabasca: Athabasca University Press.

Crook, Charles. 2012. "The "digital native" in context: tensions associated with importing Web 2.0 practices into the school setting." Oxford Review of Education 38 1: 63-80. doi:10.1080/0305498 5.2011.577946.

Cuban, Larry. 1988. "Constancy and change in schools (1880s to the present)." In Contributing to educational change: Perspectives on research and practice, edited by Philip W. Jackson: pp. 85-105. Berkeley, CA: McCutchan.

Dalsgaard, Christian. 2008. Social networking sites: Transparency in online education. Accessed 19 March 2015: www.eunis.dk/papers/p41.pdf. 
Dick, Walter, Lou Carey, and James O. Carey. 2009. The Systematic Design of Instruction, 7th ed. Upper Saddle River, NJ: Pearson Education. ISBN-10: 0205412742.

Doering, Aaron. 2006. "Adventure learning: Transformative hybrid online education." Distance Education 27 2: 197-215. doi:10.1080/01587910600789571.

Downes, Stephen. 2010. What is democracy in education? Accessed 19 March 2015: http://halfanhour. blogspot.ca/2010/10/what-is-democracy-in-education.html.

Dron, Jon and Terry Anderson. 2009. "How the crowd can teach." In Handbook of Research on Social Software and Developing Community Ontologies, edited by Stylianos Hatzipanagos and Steven Warburton: pp. 1-17. Hershey, PA: IGI Global Information Science. doi:10.4018/978-1-60566208-4.ch001.

Elavsky, C. Michael, Cristina Mislan, and Steriani Elavsky. 2011. "When talking less is more: exploring outcomes of Twitter usage in the large-lecture hall." Learning, Media and Technology 36 2: 1-19. doi:10.1080/17439884.2010.549828.

Ertmer, Peggy A. 2005. "Teacher pedagogical beliefs: The final frontier in our quest for technology integration?" Educational Technology Research and Development 53 4: 25-39. doi:10.1007/ BF02504683.

European Commission. 2013. Opening up education: Innovative teaching and learning for all through new technologies and open educational resources. Accessed 19 March 2015: http://ec.europa.eu/ education/news/doc/openingcom_en.pdf.

Folley, Susan. 2012. Bridging the gap between face-to-face and online teaching: a case study exploring tutors' early experiences of teaching online in a UK university 2009-2012. Doctoral dissertation, University of Huddersfield. Accessed 19 March 2015: eprints.hud.ac.uk/17524/1/ Sue_Folley_-_Final_Thesis.pdf.

Ford, Kasey, George Veletsianos, and Paul Resta. 2014. "The Structure and Characteristics of \#PhDChat, an Emergent Online Social Network." Journal of Interactive Media in Education. Accessed 19 March 2015: jime.open.ac.uk/article/view/2014-08/533.

Gibbons, Andrew S. and Stephen C. Yanchar. 2010. "An Alternative View of the Instructional Design Process: A Response to Smith and Boling." Educational Technology 50 4: 16-26.

Henri, F. and B. Pudelko. 2003. "Understanding and analyzing activity and learning in virtual communities." Journal of Computer Assisted Learning 19 4: 474-87. doi:10.1046/j.0266-4909. 2003.00051.x.

Herrington, Jan, Jessica Mantei, Anthony Herrington, Ian Olney, and Brian Ferry. 2009. New technologies, new pedagogies: Mobile learning in higher education. University of Wollongong. Accessed 19 March 2015: www.ascilite.org.au/conferences/melbourne08/procs/herrington-j.pdf.

Hmelo-Silver, Cindy E., Ravit Golan Duncan, and Clark A. Chinn. 2007. "Scaffolding and Achievement in Problem-Based and Inquiry Learning: A Response to Kirschner, Sweller, and Clark (2006)." Educational Psychologist. 42 2: 99-107. doi:10.1080/00461520701263368.

Hughes, Joan E. 2005. "The role of teacher knowledge and learning experiences in forming technologyintegrated pedagogy." Journal of Technology and Teacher Education 13 2: 277-302.

Ito, Mizuko, Sonja Baumer, Matteo Bittani, Danah Boyd, Rache Cody, Beck Herr-Stephenson, Heather A. Horst, Patricia G. Lange, Dilan Mahendran, Katynka Z. Martinez, C.J. Pascoe, Dan Perkel, Laura Robinson, Christo Sims, and Lisa Tripp. 2010. Hanging out, messing around, and geeking out: Kidslivingandlearning with new media. Cambridge, MA: MIT Press. ISBN 978-0-262-01336-9.

Jarmon, Leslie, Tomoko Traphagan, Michael Mayrath, and Avani Trivedi. 2009. "Virtual world teaching, experiential learning, and assessment: An interdisciplinary communication course in Second Life." Computers and Education 53 1: 169-82. doi:10.1016/j.compedu.2009.01.010.

Jenkins, Henry, Ravi Purushotma, Margaret Weigel, Katie Clinton, and Alice J. Robison. 2006. Confronting the challenges of participatory culture: Media education for the 21st century. Cambridge, MA: MIT Press. ISBN: 9780262513623 . Accessed 19 March 2015: mitpress.mit.edu/ books/confronting-challenges-participatory-culture. 
Junco, Rwy, Greg Heiberger, and Eric Loken. 2011. "The effect of Twitter on college student engagement and grades." Journal of Computer Assisted Learning 27 2: 119-32. doi:10.1111/j. 1365-2729.2010.00387.x.

Kimmons, Royce M. 2012. Identity and participation in social networking sites amongst pre-service elementary school teachers. Doctoral dissertation, University of Texas at Austin. Accessed 19 March 2015: http://repositories.lib.utexas.edu/bitstream/handle/2152/ETD-UT-2012-08-6056/ KIMMONS-DISSERTATION.pdf? sequence $=1$.

Kirschner, Paul A., John Sweller, and Richard E. Clark. 2006. "Why minimal guidance during instruction does not work: An analysis of the failure of constructivist, discovery, problem-based, experiential, and inquiry-based teaching." Educational Psychologist41 2:75-86.doi:10.1207/s15326985ep4102_1.

Lane, Lisa M. 2009. "Insidious pedagogy: How course management systems affect teaching." First Monday 14 10. Accessed 19 March 2015: http://www.uic.edu/htbin/cgiwrap/bin/ojs/index.php/ $\mathrm{fm} /$ article/view/2530/2303.

Lave, Jean and Etienne Wenger. 1991. Situated learning: Legitimate peripheral participation. Cambridge: Cambridge University Press. doi:10.1017/CBO9780511815355.

Liu, Min, Doug Williams, and Susan Pedersen. 2002. "Alien Rescue: A Problem-Based Hypermedia Learning Environment for Middle School Science." Journal of Educational Technology Systems 30 3: 255-70. doi:10.2190/X531-D6KE-NXVY-N6RE.

Lortie, Dan. 1975. Schoolteacher. Chicago: University of Chicago Press. ISBN-10: 0226493539.

Merrill, M. David. 2008. "Reflections on a Four Decade Search for Effective, Efficient and Engaging Instruction." In Michael Allen's 2008 e-Learning Annual, Vol. 1, edited by Michael W. Allen: pp. 141-67. Wiley Pfieffer. ISBN-10: 0787987433.

Miller, Charles, Simon Hooper, and Susan Rose. 2008. "Avenue ASL: Transforming curriculum through design, theory, and innovation." TechTrends 52 3: 27-32.

Moore, Michael G. 1989. "Editorial: Three types of interaction." American Journal of Distance Education 3 2: 1-7. doi:10.1080/08923648909526659.

Mott, Jon. 2010. "Envisioning the post-LMS Era: The open learning network." EDUCAUSE Quarterly 33 1: 1-9. Accessed 19 March 2015: http://www.educause.edu/ero/article/ envisioning-post-lms-era-open-learning-network.

Oliver, Martin. 2011. "Technological determinism in educational technology research: some alternative ways of thinking about the relationship between learning and technology." Journal of Computer Assisted Learning 27 5: 373-84. doi:10.1111/j.1365-2729.2011.00406.x.

Parker, Ashley. 2011. Twitter's Secret Handshake. The New York Times. Retrieved from: http://www. nytimes.com/2011/06/12/fashion/hashtags-a-new-way-for-tweets-cultural-studies. html?pagewanted=alland_r $=0$.

Paulsen, Morton Flate. 2003. "Experiences with learning management systems in 113 European institutions." Journal of Educational Technology and Society 6 4: 134-48. Accessed 19 March 2015: http://ifets.ieee.org/periodical/6_4/13.pdf.

Reeves, Thomas C. 1997. "Rigorous and socially responsible interactive learning research." Journal of Interactive Learning Research 8:151-52. Accessed 19 March 2015: http://www.aace.org/pubs/jilr/ v8n2.html\#Premiere\%20Issue\%20Preface.

Reeves, Thomas. C. 2006. "How do you know they are learning?: the importance of alignment in higher education.” International Journal of Learning Technology 2 4: 294-309. doi:10.1504/ IJLT.2006.011336.

Riel, Margaret and Linda. Polin. 2004. "Online learning communities: Common ground and critical differences in designing technical environments." In Designing for Virtual Communities in the Service of Learning, edited by Sasha Barab, Rob Kling, and James H. Gray: pp. 16-50. Cambridge: Cambridge University Press. doi:10.1017/CBO9780511805080.006.

Selwyn, Neil. 2009. "Faceworking: exploring students' education-related use of Facebook." Learning, Media and Technology 34 2: 157-74. doi:10.1080/17439880902923622. 
Selwyn, Neil. 2011. "Editorial: In praise of pessimism-the need for negativity in educational technology." British Journal of Educational Technology 42 5: 713-18. doi:10.1111/j.1467-8535. 2011.01215.x.

Simard, Caroline, Chris Stephenson, and Deanna Kosaraju. 2010. Addressing core equity issues in K-12 computer science education: Identifying barriers and sharing strategies. Palo Alto, CA: Anita Borg Institute for Women and Technology. Accessed 19 March 2015: http://csta.acm.org/ Communications/sub/DocsPresentationFiles/ABI-CSTAEquityFinal.pdf.

Smith, Kennon M. and Elizabeth Boling. 2009. "What do we make of design: Design as a concept in educational technology." Educational Technology 49 4: 3-17.

Staiano, Amanda E. and Sandra L. Calvert. 2011. "Exergames for physical education courses: Physical, social, and cognitive benefits." Child Development Perspectives 52:93-98. doi:10.1111/j.1750-8606. 2011.00162.x.

Suhonen, Jarkka and Erkki Sutinen. 2006. "FODEM: developing digital learning environments in widely dispersed learning communities." Journal of Educational Technology and Society 9 3: 43-55. Accessed 19 March 2015: www.ifets.info/journals/9_3/5.pdf.

Sweller, John, Paul A. Kirschner, and Richard E. Clark. 2007. "Why minimally guided teaching techniques do not work: A reply to commentaries." Educational Psychologist 42 2: 115-21. doi:10.1080/00461520701263426.

Thackray, Liz (n.d.). PhD Chat Wiki. Accessed 19 March 2015: http://PhDchat.pbworks.com/w/ page/33280234/PhD Chat.

Veletsianos, George. 2010. “A Definition of Emerging Technologies for Education.” In Emerging Technologies in Distance Education, edited by George Veletsianos: pp. 3-22. Edmonton, AB: Athabasca University Press.

Veletsianos, George. 2011. "Designing Opportunities for Transformation with Emerging Technologies." Educational Technology 51 2: 41-46. Accessed 19 March 2015: http://www.veletsianos.com/wpcontent/uploads/2011/02/designing-opportunities-transformation-emerging-technologies.pdf.

Veletsianos, George. 2012. "Higher education scholars' participation and practices on Twitter." Journal of Computer Assisted Learning 28 4: 336-49. doi:10.1111/j.1365-2729.2011.00449.x.

Veletsianos, George and Royce Kimmons. 2012. "Assumptions and Challenges of Open Scholarship." International Review of Research in Open and Distance Learning 13 4: 166-89. Accessed 19 March 2015: http://www.irrodl.org/index.php/irrodl/article/download/1313/2343.

Veletsianos, George and Royce Kimmons. 2013. "Scholars and Faculty Members Lived Experiences in Online Social Networks." Internet and Higher Education 16 1: 43-50. doi:10.1016/j. iheduc.2012.01.004.

Veletsianos, George, Royce Kimmons, and Karen French. 2013. "Instructor experiences with a social networking site in a higher education setting: Expectations, Frustrations, Appropriation, and Compartmentalization." Educational Technology Research and Development 61 2: 255-78. doi:10.1007/s11423-012-9284-z.

Wakefield, Jonny. 2013. President Stephen Toope talks money, MOOCs and bad reviews in annual State of UBC interview. The Ubyssey. Accessed 19 March 2015: http://ubyssey.ca/features/toope/.

Wang, Qiyun, Huay Lit Woo, Choon Lang Quek, Yuqin Yang, and Mei Liu. 2012. "Using the Facebook group as a learning management system: An exploratory study." British Journal of Educational Technology 43 3: 428-38. doi:10.1111/j.1467-8535.2011.01195.x.

Weller, Martin. 2011. "A pedagogy of abundance." Spanish Journal of Pedagogy 249: 223-36. Accessed 19 March 2015: http://oro.open.ac.uk/28774/2/BB62B2.pdf.

Wenger, Etienne. 1998. Communities of practice: learning, meaning and identity. New York: Cambridge University Press. doi:10.1017/CBO9780511803932.

West, Richard E., Greg Waddoups, and Charles R. Graham. 2007. "Understanding the experiences of instructors as they adopt a course management system." Educational Technology Research and Development 55 1: 1-26. doi:10.1007/s11423-006-9018-1. 
Wiggins, Grant and Jay McTighe. 2005. Understanding by Design, 2nd ed. Upper Saddle River, NJ: Pearson Education, Inc. ISBN-10: 1416600353.

Wilson, Brent G. 1995. "Metaphors for instruction: Why we talk about learning environments." Educational Technology 35 5: 25-30. Accessed 19 March 2015: http://carbon.ucdenver. edu/ bwilson/wils95.

Wilson, Brent G. 2004. "Designing e-Learning environments for flexible activity and instruction." Educational Technology Research and Development 52 4: 77-84. doi:10.1007/BF02504720.

Wilson, Brent G. and Patrick E. Parrish. 2011. "Transformative learning experience: Aim higher, gain more." Educational Technology 51 2: 10-15. Accessed 19 March 2015: http://carbon.ucdenver. edu/ bwilson/TLE.pdf.

Wilson, Brent G., Patrick E. Parrish, and George. Veletsianos. 2008. "Raising the bar for instructional outcomes: Toward transformative learning experiences." Educational Technology 48 3: 39. 